DOI: $10.31866 / 2410-1915.20 .2019 .172468$

УДК 78.071.2

\title{
ГОТОВНІСТЬ ДО ІННОВАЦІЙ МУЗИКАНТА-ФАХІВЦЯ У ВТІЛЕННІ ЦИВІЛІЗАЦІЙНОЇ СПЕЦИФІКИ МУЗИЧНОГО ПРОФЕСІОНАЛІЗМУ
}

\section{Шевченко Лілія Михайлівна}

Кандидат педагогічних наук, доцент, ORCID: 0000-0001-8602-9573, lilia.my.forte@gmail.com, Одеська національна музична академія ім. А. В. Нежданової, вул. Новосельського, 63, Одеса, Україна, 65023

Метою статті є висвітлення механізму мислення та загально-психологічних засад творчості як складової діяльнісної ініціативи музикантів.

Наукова новизна полягає у тому, що вперше в мистецтвознавстві, через зіставлення спостережень фахівців та розуміння аперцепції (процес, в результаті якого елементи свідомості стають чіткими), на основі якої була сформульована теоретиками ренесансу діалогіка як закон авторського відкриття, заявлена концепція творчого злету як діяльнісна пролонгація психологічної установки на інноваційну готовність фахівця до поєднання напрацювань професійної традиції із замовленою соціумом цілеспрямованістю дій.

Методологічною основою дослідження стали аналітичний, порівняльноісторичнийтапсихологічно-установочнийпідходи,якідозволилишляхомпорівняння встановити схожість і відмінність між історичними явищами у забезпеченні взаємодії науково-творчих і художньо-поетичних рішень в діяльності музикантафахівця як принципово аналогічних сфер діяльності та подальших розробках цієї концепції.

Крім того, застосовано метод мистецькознавчого стильового компаратива як механізм художнього мислення, що спонукає до активного пошуку створення нових зразків творчої й педагогічної діяльності та вибору серед них найбільш ефективних методів.

Висновки. Доведено, що механізм художнього мислення надихає музикантафахівця, педагога до активного пошуку, створенню нових зразків творчої й педагогічної діяльності та вибору серед них найбільш ефективних. Але реалізація його у творчий продукт залежить не тільки від індивідуальних намірів, але й від зовнішньо-соціальних обставин, які обумовлюють міру і напрямок здійснення індивідуальних потреб в самостійному цілеспрямуванні музиканта-фахівця. Саме наявність останнього разом із накопиченням досвіду, за законом ренесансної діалогіки, покликані ввести спеціаліста в активний пошук, підсумком якого виступає інноваційна конкретика творчого відкриття.

Таким чином, готовність музиканта до інновацій у професійній діяльності визначається як стійкий новотвір у структурі особистості музиканта, що проявляється в спрямованості його дій на постійне вдосконалення, оптимізацію й відновлення

(C) Шевченко Л. М., 2019 
професійної діяльності, реалізованої у навчанні, розвитку та вихованні як особисто, так й в учнях.

Ключові слова: готовність до інновацій; музикант-фахівець; музичний професіоналізм; цивілізаційна специфіка діяльності; діяльність.

\section{Вступ}

Запорукою життєздатності фахівця і його спроможності на невтомний творчий пошук стає музична практика. Художня специфіка артистичної діяльності має опиратися на механізм мислення, в якому закладена готовність до інновацій, яка $є$ складним новоутворенням у структурі особистості, яким $є$ готовність до музично-творчої діяльності. Відповідно до змісту поняття «інновація» їі можна охарактеризувати як наявність у музиканта внутрішньої та зовнішньої спрямованості до розвитку, удосконалення і перетворення своєї діяльності. Тож активний пошук, підсумком якого виступає інноваційна конкретика творчого відкриття та загально-психологічні засади творчої діяльності як складової діяльнісної ініціативи людей, загалом залишаються актуальними.

Виходячи з вищезазначеного, наголошуємо на необхідності аналізу джерел виникнення у музиканта готовності до інновацій та аналізу механізму розвитку діяльності як такої. А також виявлення загальних закономірностей виникнення інновацій у будь-якої діяльності й особливо художньої, зокрема притаманних професійній діяльності музикантафахівця.

Методологічною основою дослідження стали аналітичний, порівняльно-історичний та психологічно-установочний підходи, які дозволили шляхом порівняння встановити схожість і відмінність між історичними явищами у забезпеченні взаємодії науково-творчих і художньо-поетичних рішень у діяльності музиканта-фахівця як принципово аналогічних сфер діяльності та подальших розробках цієї концепції.

Крім того, застосовано метод мистецькознавчого стильового компаратива як механізм художнього мислення, що спонукає до активного пошуку створення нових зразків творчої й педагогічної діяльності та вибору серед них найбільш ефективних методів.

Розуміння творчості як мисленневого важеля оновлення його апріорних позицій закладено у дослідженнях О. Лосєва, Ф. Топорова, Б. Поршнєва, Л. Шевченко. Зокрема, В. Топоров (Топоров 1988, с. 26-48.) досліджуючи ритуал як наукову проблему наголошує, що міф та ритуал відображають перехід від природного і біологічного до культурного і соціального. Також Л. Шевченко (Шевченко, 2000) визначає поняття готовності до професійної діяльності, виокремлює її різновиди, підходи до iiï досягнення та компоненти готовності майбутнього педагога-музиканта.

Готовність до інновацій неодноразово розглядалася такожу мистецтвознавчій літературі, коли вивчали імена визначних митців та їхній внесок у світову культуру (Альшванг (1977); Мартынов (1974); Нестьев (1973); Соловцов (1960). 
Однак, попри існуючий доробок історіографії наявною є низка певних проблем, які ще не знайшли достатнього висвітлення та потребують детального вивчення. Зокрема, окремо не розглядалася характеристика мисленнєвого механізму, який народжує новаційні позиції у творчості, демонструє зв'язок творчих відкриттів із загально-мисленневими навичками, а тим самим вказує шлях навчання у творчій роботі.

\section{Мета статті}

Метою розвідки $є$ висвітлення механізму мислення та загальнопсихологічних засад творчості як складової діяльнісної ініціативи музикантів.

Наукова новизна полягає у тому, що вперше в мистецтвознавстві, через зіставлення спостережень фахівців та розуміння аперцепції (процес, в результаті якого елементи свідомості стають чіткими), на основі якої була сформульована теоретиками ренесансу діалогіка як закон авторського відкриття, заявлена концепція творчого злету як діяльнісна пролонгація психологічної установки на інноваційну готовність фахівця до поєднання напрацювань професійної традиції із замовленою соціумом цілеспрямованістю дій.

Вважаючи на те, що діяльнісна активність регулюється психічними установленнями аперцепції, тобто виробленими суб'єктивним (індивідуальним чи колективним) досвідом мисленневих стереотипів реакції на зовнішні впливи, мусимо усвідомлювати органіку адаптації останніх до установлень суб'єкта, а, значить, готовності гнучко погоджувати відомі 3 відмінними нормативами. Механізм адаптації передбачає засвоєння незнайомого, складаючи біологічно-психологічну передумову іноваційної продукції суб'єкта активності. Вказана сторона мислиннєвих операцій співпадає 3 механікою тропування-метафоризації в художньо-творчих діяльнісних виходах, в яких єдність суб'єкта-об'єкта у вираженні утворює аксіоматичне тло творчих операцій загалом.

Вказана метафорична підоснова, визнана базою розуміння художньообразних рішень, перекликається з науково-творчими механізмами, що зафіксовано поняттям ренесансної «діалогіки» і має виходи на метод аналогії як спосіб заохочення творчого пошуку (не будучи засобом доказу), на етимологічний підхід, який на певних етапах позитивістської абсолютизації експерименту не вважався науковим за його внутрішній зв’язок з аналогізаційними операціями (Борев, 1975). Ці мислево-розумові й віросповідально-поєднальні типології як стимул творчої роботи прекрасно усвідомлювали організатори й діячі перших консерваторій, які заклали базис музичної освіти і системи професійного музичного мислення загалом.

У XVII-XVIII ст. наскрізним, протягом усього навчання (від 7 до 15 років), було штудіювання філософії, Богослов'я-теології, навчання чотирьом мовам та ін. в паралель до об'ємного засвоєння саме музичних теорії й практики (Барбье, 2006), забезпечували взаємодію науково- 
творчих і художньо-поетичних рішень у діяльності музиканта-фахівця як принципово аналогічних сфер діяльності. I, переважно, забезпечували вказані взаємодії - гнучкі поєднання сакрального - профанного, наукового - творчо-художнього, що й сьогодні вражають гігантизмом творчих досягнень як в науковій, так і в творчо-практичній сферах.

Звернімо увагу на те, що деякі автори, розглядаючи концепції діяльності, відмовилися від терміну «трудова діяльність», вважаючи за необхідне оперувати поняттям предметної діяльності. Даний підхід цілком приймається музикантами й представниками сфери мистецтва загалом, оскільки історія людства засвідчує, що саме специфічно людський характер діяльнісного виявлення забезпечується ритуальноцеремоніальною активністю. Адже, трудових зусиль у розумінні подальших епох первісна людина не робила та й не могла робити, оскільки вихідним та стрижньовим для неї була віросповідальна спрямованість дій, що й виражалося у «надлишковому» (за вимірами цивілізаційних трактувань) зосередженні на ритуалах-обрядах (Топоров, 1988).

Це нагадування історичних витоків людського культуротворення аргументує вагомість розуміння діяльності як предметно спрямованої, причому, предметом цього спрямування виступає епохально детермінований «дух епохи» (Гегель, 1958, с. 94-156) мисленневий тип віросповідальної активності.

Вказаний принцип дещо парадоксально віддзеркалювався у вихідній вимозі до «абітурієнтів» італійських консерваторій XVII-XVIII ст.: претендент на навчання повинен бути охрещеним (Барбье, 2006). I якщо ревнителі «прогресу» вбачали у цій вимозі «церковний гніт» щодо мисленнєвих установлень майбутніх учнів, то, з позицій сьогоднішньої недовіри до лінійно-історичних підходів «прогресистів», підкреслимо культуротворчий стимул цієї вимоги, оскільки повнота ідеальної абстракції музики i реальна надскладність засвоєння навчання у масштабах перших консерваторій не могли бути осягнені учнями, якщо до цього не підключалася енергетика віросповідальної пристрасті й довіри до Вищої Досконалості буття.

Адже для віруючого найскладніші зусилля розумового й фізичного характеру спрямовані на перетворення дійсності згідно з божествено закладеною в людину здатністю ангелоподоби (Мартынов, 2000). Атеїствуючі філософи Західної Європи XVII-XVIII ст. внесли позацерковний аспект в ту формулу, замінивши мету діяльнісного перетворення дійсності на раціонально-логічно усвідомлювану «користь людині», врешті-решт, ототожнювану з матеріально-споживчим забезпеченням. I така мета не залишала місця музиці як високому мистецтву, що й спостерігаємо на постіндустріальному-посткультурному роздоріжжі сьогоденності.

Результуючим уявленням про діяльність привело до розуміння іï як особливої людської форми активного відношення до світу, характерною рисою якої виступає необмежена здатність суб'єкта до перегляду й удосконалювання вже відомих і використовуваних програм, способів взаємодії зі світом. Із цього виходить, що діяльнісний зв’язок людини 
з природним оточенням складається не в простому підпорядкуванні їі своїй меті, а в спрямуванні цих цілей до природної сутності. Але це вже звучить майже утопічно, оскільки культурна штучність людини таку раціонально спрямовану «на природу» діяльність буде жорстко корегувати утвореними стереотипами...

Як бачимо, розвиток не забезпечується використанням наявного суспільного (соціального) досвіду. Воно дозволяє розширення, поглиблення цього досвіду, його переходу з результативно-предметної форми існування у ідеально-діяльну. Розпредмечування соціального досвіду в діяльності Й опредмечення його у власних засобах i результатах діяльності $€$ для людини механізмом його розвитку як суб'єкту. Симптоматично, що у виробництві, де процес обміну продуктами дозволяє відтворення вже раніше поставленої й реалізованої мети, філософи не знаходять місця цілеспрямуванню як вільному самовираженню суб’єкта: «... той факт, що людина при цьому діє доцільно, зі знанням справи, нічого в цьому змісті не міняє». І далі: «У праці, орієнтованій на меті споживання, людина, отже, не виступає в якості цілеспрямовано діючого суб’єкта. Сама постановка мети $є$ тут не моментом цілеспрямування, а, навпаки, спрямування до зовнішніх цьому процесу меж - саме зовнішніх, оскільки способи реалізації Мети, за визначенням, не можуть бути представлені в самому процесі Цілеспрямування» (Шевченко, 2000).

Таким чином, об ’єктивний початок у діяльності знаходить свій прояв у характеристиках їі предметного змісту, яке фіксує перетворюючі або створювані якості Дійсності. Також це результати або продукти цього перетворення, що надають соціального змісту діяльності. Нарешті, предметний зміст діяльності усвідомлюється за способами досягнення результатів, що матеріалізують сам процес перетворення. Суб'єктивний початок знаходить своє послідовне вираження в реальних формах втілення об’єктивного змісту діяльності. Уже в силу своєї належності суб'єктові діяльності воно обумовлено неповторністю, унікальністю його психічних можливостей, особистісних переваг і індивідуального життєвого досвіду.

Саме відношення об’єктивного й суб’єктивного надає діяльності риси узагальненого й окремого та є джерелом протиріч, що впливають на їі розвиток. Але сам шлях, яким піде розвиток діяльності, вибір способу усунення протиріччя між об’єктивним i суб'єктивним, визначається суб’єктом. Від нього залежитиме чи повністю підкоритися вимогам об’єктивного, що спричинить збереження й відтворення вже відомих зразків діяльності, або через цілеспрямування затвердити власне бачення предмета й способи його перетворення, створюючи тим самим унікальний зразок діяльності.

Важливо те, що й у першому, і в другому випадку регулятором активності суб'єкта виступає його свідомість. Саме у свідомості суб'єкта об’єктивні властивості предмета й вимоги діяльності погоджуються, співвідносяться 3 реальними можливостями й інтересами самого діяча. Виносячи у свідомості ідеальний план діяльності, суб'єкт задає її загальну орієнтацію, мобілізує психічні процеси або на задоволення об’єктивних 
вимог діяльності (тобто збереження іiї стійкості), або на їх подолання (тобто приведення її в стан нестійкості, розвитку).

У будь-якому випадку свідомість виконує роль системоутворюючого фактора, що погоджує всі рівні забезпечення діяльності воєдино й визначає загальний характер взаємодії її елементів. Саме свідомість виступає детермінантою змін у діяльності, внутрішньою, сутнісною передумовою iii розвитку. Конкретизація наведених вище міркувань у контексті професійної діяльності музиканта-фахівця дозволяє говорити про те, що розвиток, удосконалювання цієї діяльності залежить від особливостей подолання творчою особистістю протиріччя між іiі об'єктивним і суб'єктивним початком.

Об'єктивне проявляє себе у тому, які перетворювальні або створені якості творчого процесу його учасників фіксуються в предметному змісті професійної діяльності музиканта-фахівця. Також це результати, що надають соціального змісту його професійній музично-творчій діяльності. Об’єктивний початок виражається у способі досягнення результатів, у чому конкретно матеріалізується діяльність музиканта-фахівеця. Суб’єктивне ж проявляє себе в тому, як особистість приходить до цього результату: чи буде вона змінювати саму себе, освоєну схему діяльності стосовно до особливостей ситуації, яка складається під впливом особливостей індивідуальності оточення, або буде намагатися змінити останнє, задля існуючих схем, програмам, закликів музично-творчої діяльності.

Очевидно, що від того, яке рішення прийме музикант-фахівець залежитиме чи буде його музично-творча діяльність здійснюватися в рамках репродукування вже відомих зразків цієї діяльності, або змінюватися, удосконалюватися завдяки створенню нових зразків, тобто за рахунок інновацій. Вибір визначаєтиметься творчим індивідом. Більш конкретно - відкритістю його свідомості до сприйняття й створення нового.

Зовнішні - об'єктивні - передумови інновацій зумовлюються реальністю процесів буття, в якому розвиток як такий детермінує перетворення діяльнісної активності у фахово-спеціалізований акт. I це перетворення здійснюється як би в двох вимірах: як проста схема автономно й незалежно формованих рівнів організації цієї діяльності або як складне суперечливе переростання простих і загальних форм у більш складні й специфічні (Шевченко, 2000).

Саме факт виникнення діяльності як соціальної форми прояву активності людини спрямовує їі до якісних змін. Серед таких змін на шляху соціалізації прийнято вважати працю. За своїм змістом й за реалізованими функціями вона виявляє нову якість діяльності, специфічну форму її існування, що, переборовши рамки біологічного, розвивається на шляху переходу людського буття від найпростіших індивідуальних форм до соціальних.

Предмет праці і його цілі задаються не тільки самим діячем, але й тим, хто буде використовувати, споживати продукти цієї праці. Воля суб'єкта діяльності в праці проявляється у технології виробництва необхідного 
продукту. Завдяки волі суб’єкт зберігає можливість реалізації в праці своєї індивідуальності. Соціальне протистає індивідуальному, але не поглинає його.

Закони розвитку праці, як відомо, спричинили не тільки його поділ на окремі сфери виробництва, але й на окремі технологічні операції. Спеціалізація стає законом підвищення її ефективності. Але при цьому індивідуальна воля суб'єкта у виборі способу виробництва певного продукту повністю поглинається діями інших суб'єктів у технологічному ланцюжку. Стандартизація у якості виробленого товару стає умовою його масового відтворення й, поряд із цим, регламентацією індивідуальних проявів суб'єктів праці усередненими можливостями колективного суб'єкта.

Технологія виготовлення продукту, ніби знімається із процесу роботи й сама стає товаром, тобто особливим продуктом, що володіє соціальною цінністю, специфічні форми праці обрамлюються якісно й віддаляються у своєму існуванні одне від одного функціями професії.

Але все це маємо в праці-виробництві, тобто праці, безпосередньо розрахованої на споживання і продукти якої задовольняють матеріальні потреби людей. У сфері культури, де ритуал і самодостатня творчість не виходять безпосередньо на речові здобутки i демонструють ідеальні цінності енергетичного піднесення суб'єктів-учасників акції, перетворюваною якістю виступає стан-мислення останніх. I професійні диференціації не складають тих стрижньових утворень, які тримають соціальні засади цивілізаційованого суспільства.

Саме професія поєднує та інтегрує людей, визначаючи їхню подібність у поглядах, оцінках, нормах поведінки й діяльності, поглинаючи індивідуальне буття соціальним способом існування. Будучи включеною в систему суспільного виробництва й відповідних їй суспільних відносин, професія утворює в них самостійну структуру, що стає об'єктом цілеспрямованого регулювання 3 боку суспільства і його державних важелів. Суспільство здійснює контроль за результатами спеціалізованої трудової діяльності, воно ж забезпечує її стандартизацію й регламентацію в розвитку якості, створюючи спеціальні інститути для здійснення професійної діяльності. І все ж навіть у суто виробничій-відтворювальній сфері має місце відтворення досвіду, що переносить цього роду діяльність з плану матеріального в ідеальний.

Саме продукти праці й різноманіття технологій обумовлюють необхідність уніфікації їхнього змісту й подання індивідуального досвіду в синтезованій і загальній формі - у вигляді знання. Важливим $є$ й те, що знання як опредмечений в ідеальному плані процес створення необхідного продукту, на відміну від безпосереднього індивідуального досвіду його виробництва, піддається трансляції, тобто передачі, поширенню в просторі й часі. Воно може доповнюватися, змінюватися у своєму змісті, усе більше збагачуючись індивідуальним досвідом і наповнюючись суспільним змістом. У такому виді саме знання стає об'єктом привласнення. Воно дозволяє швидше, без зайвих витрат на помилки, опановувати технологію праці та залучати досвід інших людей. 
Ідеальні предмети знання виробничого й виробничого-відтворювального процесів поєднуються своєю позаматеріальною визначеністю, допускаючи різні форми взаємодії і дифузії, живлячи виробничовідтворювальні дії цілеспрямованістю до Високого, і вносячи в ритуальноцеремоніальність буттєву заклопотаність речовим надбанням. Склався спеціальний діяльнісний шар виробництва знання, що означає «отоварювання» ідеального здобутку як «мутанта» ідеальності в межах виробничого тоталітаризму суспільства споживання.

Виробництво знань й необхідність їхнього збереження через передачу від покоління до покоління $є$ тією соціальною потребою, задоволення якої привело до оформлення творчої, музично-творчої праці в її специфічній соціальній функціі. Здатність виробляти товар, що володіє високою соціальною значимістю, дозволяє прискорювати розвиток окремих видів праці, удосконалювати технологію іiї виявлення. Таким чином, творча, педагогічна діяльності самі по собі тривалий час залишалися мистецтвом. Ïї технології не піддавалися масовому відтворенню й зберігали риси унікальності й неповторності.

І все ж об’єктивна потреба в підвищенні ефективності суспільного буття, можливість рішення певних завдань творчого озброєння економічними засобами за рахунок масового навчання й виховання привели до того, що технологія творчої діяльності була опредмечена в знанні й стала предметом засвоєння й відтворення. Масове навчання й виховання як продукти творчо-педагогічної діяльності, усвідомлення їхньої соціальної значимості, привели до того, що діяльність творчих працівників, педагогів із належними їм особливими спеціальними функціями займає чільне місце в системі життєдіяльності суспільства. Творча, педагогічна діяльності досягають своєї зрілості в процесі становлення відповідних професій.

Фортепіанне виробництво України (коли вже йдеться про взаємодію матеріально-виробничих і художньо-творчих процесів) спрямоване на фахівську озброєність, зокрема, це готовність до адаптації в нових умовах творчого буття. А останні віддзеркалюють певні тенденції планетарного обсягу, з яких найбільш болісно усвідомлюється категоричне зменшення попиту на фортепіанно-сольні концерти, на клавірабенди, що за кілька десятиліть до сьогодення складали атрибутику артистичного самоствердження піаніста.

У сучасних умовах не програмно оформлений перелік виконуваних творів, але «проект», тематично-літературно сформульований, вирішує долю допуску піаністів до філармонічної естради, - а хіба ж типу «Бах перезавантаження» у виконанні О. Ботвіновим бахівських Гольдбергівських варіацій в контрапункті з перкусією турецького джазиста. Надлишкова, мабуть, широта фортепіанного репертуару не заслоняє потреби у віртуозів рівня М. Плетньова, М. Аргеріх та ін. робити авторські перекладення відомих симфонічних, балетних, оперних творів для фортепіано (для двох фортепіано), відновлюючи, фактично, традицію транскрипцій XIX ст., тільки в певній чіткості «аутентичних» композиційних прочитань вихідного тексту. 
Поставангард у світі й Україні надихнув музикантів стерти всі професійні розмежування, стимулюючи концерти-композиції, концертирозповіді, концерти з активним відеорядом і з елементами діалогу зі слухачами, особливо це стосується виступів з імпровізаціями, якими нещодавно виблискувала піаністична Одеса під час виступів Ю. Кузнєцова, С. Терентьєва. Педагогічний зріз оголяється в спеціалізаціях виходів на дитячу, молодіжну і «традиційну» філармонічну аудиторії, кожна 3 яких заслуговує свого репертуарного вибору і спеціального виразного тонусу подання композицій, імпровізацій та позамузичних компонентів концертного спілкування.

Маючи професійне обрамлення, творча діяльність у своєму бутті постає як нова соціальна сутність, що об’єктивно підкорює собі індивідуальну свідомість і потенційні можливості митця як суб'єкта праці. Її подальший розвиток визначений зовнішніми соціальними обставинами й залежить від того, якою мірою та напрямку творча особистість як суб’єкт мистецької праці зможе реалізувати свої індивідуальні можливості й потреби для цілеспрямування. А останнє кінцевою метою поєднується з ідеальним здобутком перетворення людини в наближеності до Досконалості Світобудови й надихається Вірою у релігійні цінності чи в ті, що їх переконливо заміщують у конкретних соціальних реаліях.

Таким чином, передумовами виникнення інновацій у професійній діяльності музиканта-митця, педагога варто вважати його індивідуальну свідомість, що володіє властивістю відкритості як до оволодіння нормативами і типологіями, так і до переступання їх заради «адаптації» до вражень і здобутків буття. Індивідуальна свідомість творчого працівника черпає в механізмах тропування-метафоризації, що зумовлюють не тільки смисл-структуру образу-твору як оречовленого в матеріальних вимірах продукту праці, але й принципи мислення у процесі відтворення фахівської когорти, тобто в педагогічних установках.

Для піаністів останнє чітко проявляється в відео-мовленнєвому «тропуванні» того, що грається, і не стільки у супроводі кваліфікованого конферансьє, скільки у мобілізації артистично-лицедіючого партнерства, а то й набирання самим піаністом виразних прийомів 3 арсеналу театральних акторів. Все диктує сучасним педагогам-піаністам палітру навичок, серед яких традиційна академічна «чиста» гра може складати стрижень, системотворчий принцип, але не весь артистичний вихід.

Внутрішні суб'єктивні й зовнішні об'єктивні передумови виникнення інновацій у професійній діяльності музиканта-професіонала, виконавцякомпозитора, педагога й теоретика-музикознавця, визначають теоретикометодологічну базу виділення закономірностей процесу інноваційно спрямованої творчості в різновидах фахової діяльності музиканта. Позаакадемічні прийоми гри й поведінки на сцені програмують навчання останнім, причому із широти артистичного запасу в цілому, від гнучкості володіння теоретичними позиціями, які достатньо чітко здатні спрямувати комбінаторику мислення в аудиторії відповідних фахівських переваг. 


\section{Висновки}

Отже, механізм художнього мислення надихає музиканта-фахівця, педагога до активного пошуку, створення нових зразків творчої й педагогічної діяльності та вибору серед них найбільш ефективних. Але яким чином буде ця готовність реалізована і чи буде втілена у творчий продукт взагалі - залежить не стільки від індивідуальних намірів, але й від зовнішньо-соціальних обставин. Вони обумовлюють якою мірою і напрямком музикант-фахівець як суб'єкт професійної діяльності зможе здійснити свої індивідуальні можливості й потреби в самостійному цілеспрямуванні. Саме наявність останнього разом із накопиченням досвіду, за законом ренесансної діалогіки, покликані ввести спеціаліста у активний пошук, підсумком якого виступає інноваційна конкретика творчого відкриття.

Таким чином, готовність музиканта до інновацій у професійній діяльності визначається як стійкий новотвір у структурі особистості музиканта, що проявляється в спрямованості його дій на постійне вдосконалення, оптимізацію й відновлення професійної діяльності, здійснюваної у навчанні, розвитку та вихованні як особисто, так й в учнях. А саме, в умінні критично оцінювати продуктивність своїх дій і гнучко змінювати їх залежно від обставин конкретної творчої ситуації, можливостей суб 'єкта цього процесу в досягненні своїх цілей у музичній сфері та знання законів і закономірностей про технологію i методику оптимізації художньо-творчого, педагогічного процесу, про засоби удосконалення такого роду діяльності у зв'язку з потребами й можливостями саморозвитку творчої особистості і розвитку учня, а також у емоційно-позитивному відношенні до проблем особистості музиканта, упевненість у можливості їх подолання засобами гнучкої організації творчо-продуктивної діяльності.

\section{Список використаних джерел}

1. Альшванг А. А. Людвиг ван Бетховен : очерк жизни и творчества. Москва : Музыка, 1977. 447 с.

2. Барбье П. История кастратов / пер. с фр. Е. Рабинович. Санкт-Петербург : Изд-во Ивана Лимбаха, 2006. 302 с.

3. Баткин Л. М. Итальянские гуманисты: стиль жизни и стиль мышления. Москва : Наука, 1978. 198 с.

4. Борев Ю. Б. Эстетика. Москва : Политиздат, 1975. 399 с.

5. Выготский Л. С. Психология искусства. Москва : Искусство, 1965. 378 с.

6. Гегель Г. Сочинения : в 14 т. / пер. Б. Г. Столпнера. Москва : Соцэкгиз, 1938. Т. 12: Лекции по эстетике. Кн. 1. С. 416-418.

7. Гегель Г. Сочинения : в 14 т. / пер. П. С. Попова. Москва : Изд-во соц.эконом. лит., 1958. Т. 14 : Лекции по эстетике. Кн. 3. С. 94-156.

8. Мартынов В. И. Культура, иконосфера и Богослужебное пение Московской Руси. Москва : Прогресс-Традиция ; Русский путь, 2000. 224 с. 
9. Мартынов И. И. Сергей Прокофьев : жизнь и творчество. Москва : Музыка, 1974. $560 \mathrm{c}$.

10. Нестьев И. Жизнь Сергея Прокофьева. Москва : Сов. Композитор, 1973. 655 с.

11. Соловцов А. А. Фридерик Шопен. Жизнь и творчество. Москва: Музгиз, 1960. 467 c.

12. Топоров В.Н. О ритуале. Введение в проблематику. Архаический ритуал в фольклорных и раннелитературных памятниках. Москва : Наука, 1988. С. 26-48.

13. Шевченко Л. М. Формирование готовности музыканта-педагога к инновациям в профессиональной деятельности : дис... канд. пед. наук: 13.00.04 / Южно-Украинский гос. пед. ун-т им. К. Д. Ушинского. Одесса, 2000. 187 с.

\section{References}

Alshvang, A.A. (1977). Liudvig van Betkhoven: Ocherk zhizni i tvorchestva [Ludwig van Beethoven: Essay on Life and Oeuvre]. Moscow: Muzyka.

Barbe, P. (2006). Istoriia kastratov [Castratos` history] Translated from French by E. Rabinovich. St. Petersburg: Izdatelstvo Ivana Limbakha.

Batkin, L.M. (1978). Italianskie gumanisty: stil zhizni i stil myshleniia [Italian humanists: lifestyle and thinking style]. Moscow: Nauka.

Borev, Yu.B. (1975). Estetika [Aesthetics]. Moscow: Politizdat.

Gegel, G. (1938). Lektcii po estetike [Lectures on aesthetics]. In: Sochineniia [Writings]. Translated from German by B.G. Stolpner. Moscow, vol. 12, pt. 1, pp. 416-418.

Gegel, G. (1958). Lektcii po estetike [Lectures on aesthetics]. In: Sochineniia [Writings]. Translated from German by P.S. Popov. Moscow, vol. 14, pt. 3, pp. 94-156.

Martynov, I.I. (1974). Sergei Prokofev: Zhizn i tvorchestvo [Sergey Prokofiev: Life and Work]. Moscow: Muzyka.

Martynov, V.I. (2000). Kultura, ikonosfera i Bogosluzhebnoe penie Moskovskoi Rusi [Culture, Iconosphere and Worship of Moscow Russia]. Moscow: Progress-Traditciia. Nestev, I. (1973). Zhizn Sergeia Prokofeva [Sergei Prokofiev` life]. Moscow: Sov. Kompozitor. Shevchenko, L.M. (2000). Formirovanie gotovnosti muzykanta-pedagoga $k$ innovatciam $v$ professionalnoi deiatelnosti [Formation of the openness of a teacher of music for innovations in professional activity]. D.Ed. South Ukrainian National K.D. Ushynsky Pedagogical University. Odessa.

Solovtcov, A.A. (1960). Friderik Shopen. Zhizn i tvorchestvo [Frederic Chopin. Life and Oeuvre]. Moscow: Muzgiz.

Toporov, V.N. (1988). O rituale. Vvedenie v problematiku [About the ritual. Introduction to the issue]. Arkhaicheskii ritual $v$ folklornikh i ranneliteraturnykh pamiatnikakh [Archaic ritual in folklore and early literary monuments]. Moscow, pp. 26-48.

Vygotskii, L.S. (1965). Psikhologiia iskusstva [Art psychology]. Moscow: Iskusstvo. 


\title{
OPENNESS OF THE EXPERT MUSICIAN TO INNOVATIONS TO INTRODUCE CIVILIZATIONS SPECIFICS OF THE MUSICAL EXCELLENCE
}

\author{
Liliia Shevchenko
}

\author{
Ph.D. in Pedagogy, Associate Professor, \\ ORCID:0000-0001-8602-9573, lilia.my.forte@gmail.com, \\ Odesa National A. V. Nezhdanova Academy of Music, \\ Odesa, Ukraine
}

The aim of the research is to highlight both the mechanism of thinking and general psychological principles of creativity as part of the musicians`activity initiative.

The scientific novelty of the research lies in the fact that for the first time in art studies, through the comparison of observations of experts and understanding of apperception (the process in which the elements of consciousness become clear), on which the Renaissance scientists formulated the term Dialogics as the law of the author's discovery, the concept of creative roll is declared as an active prolongation of psychological pattern for the expert to be ready for innovations to combine the experience of a professional tradition with action motivation quoted by society.

Methodology of the research has been analytical, comparative-historical and psychological-orientational approaches, which allowed by comparison establishing the similarity and the difference between historical phenomena in ensuring the interaction of scientific-creative and artistic and poetic decisions in the activities of the expert musician as essentially similar fields of activity and further development of this concept.

In addition, the method of art style comparative art as a mechanism of artistic thinking is used, which prompts an active search to create new samples of creative and pedagogical activity and to choose the most effective methods among them.

Conclusions. It is proved that the mechanism of artistic thinking inspires the expert musician and a teacher for active search, to create new samples of creative and pedagogical activity and to choose among them the most effective ones. However, its implementation in the creative product depends not only on individual intentions, but also on the externalsocial circumstances that determine the extent and direction of the implementation of individual needs in the independent targeting of the expert musician. It is the latter, together with the accumulation of experience, in accordance with the law of the Renaissance Dialogics, that designed to introduce the expert into an active search, where the innovative specificity of creative discovery is a result.

Thus, the musician's readiness to innovate in professional activity is defined as a stable new formation in the structure of the musician personality, which manifests itself in the direction of his actions for the continuous improvement, optimization and restoration of professional activity, realized in teaching, development and education both personal and for students.

Keywords: openness to innovations; expert musician; musical excellence; civilization specificity of activity; activity. 


\title{
ГОТОВНОСТЬ К ИННОВАЦИЯМ МУЗЫКАНТА-СПЕЦИАЛИСТА В ВОПЛОЩЕНИИ ЦИВИЛИЗАЦИОННОЙ СПЕЦИФИКИ МУЗЫКАЛЬНОГО ПРОФЕССИОНАЛИЗМА
}

\author{
Шевченко Лилия Михайловна
}

Кандидат педагогических наук, доцент, ORCID: 0000-0001-8602-9573, lilia.my.forte@gmail.com, Одесская национальная музыкальная академия им. А. В. Неждановой, Одесса, Украина

Целью статьи является освещение механизма мышления и общих психологических основ творчества как составной деятельностной инициативы музыкантов.

Научная новизна заключается в том, что впервые в искусствоведении, через сопоставление наблюдений специалистов и понимание аперцепции (процесс, в результате которого элементы сознания становятся четкими), на основе которой была сформулирована теоретиками ренессанса Диалогика как закон авторского открытия, заявленная концепция творческого взлета как деятельностная пролонгация психологической установки на инновационную готовность специалиста к объединению наработок профессиональной традиции с заказной социумом целеустремленностью действий.

Методологической основой исследования стали аналитический, сравнительно исторический и психолого-установочный подходы, которые позволили путем сравнения установить сходство и различие между историческими явлениями в обеспечении взаимодействия научно-творческих и художественно-поэтических решений в деятельности музыканта-специалиста как принципиально аналогичных сфер деятельности и дальнейших разработках этой концепции.

Кроме того, применен метод искусствоведческого стилевого компаратива как механизм художественного мышления, побуждает к активному поиску создания новых образцов творческой и педагогической деятельности и выбора среди них наиболее эффективных методов.

Выводы. Доказано, что механизм художественного мышления вдохновляет музыканта-специалиста, педагога к активному поиску, созданию новых образцов творческой и педагогической деятельности и выбора среди них наиболее эффективных. Но реализация его в творческий продукт зависит не только от индивидуальных намерений, но и от внешнеэкономической социальных обстоятельств, которые обусловливают меру и направление осуществления индивидуальных потребностей в самостоятельной целенаправленности музыканта-специалиста. Именно наличие последнего вместе с накоплением опыта, по закону ренессансной Диалогики, призванные ввести специалиста в активный поиск, итогом которого выступает инновационная конкретика творческого открытия.

Таким образом, готовность музыканта к инновациям в профессиональной деятельности определяется как устойчивое новообразование в структуре личности музыканта, проявляется в направленности его действий на постоянное совершенствование, оптимизацию и восстановление профессиональной деятельности, реализованной в обучении, развитии и воспитании как лично, так и в учениках.

Ключевые слова: готовность к инновациям; музыкант-специалист; музыкальный профессионализм; цивилизационная специфика деятельности; деятельность. 